\title{
Scanning Electron Microscope Observations of the Synovial Membrane of Rabbit Knee Joints after Experimentally Induced Hemarthrosis
}

\author{
Paolo Cherubino* and Katsuko Kataoka
}

\author{
Received March 30, 1973
}

Summary. The synovial membrane of normal and experimentally induced hemarthrotic knee joints of the rabbit was studied using the scanning electron microscope. In a normal synovial membrane, three kinds of villi are recognized: a) macrovilli observed easily with low magnification stereomicroscopy, b) medium size villi corresponding to protruded synovial lining cells and large cytoplasmic processes and c) microvilli equivalent to fine cytoplasmic processes. Early reactions of the synovial surface to the blood injection are seen in medium size villi and microvilli, which increase in number and size. Subsequently hypertrophy and hyperplasia of macrovilli take place. By light microscopy of the synovial fluid, phagocytosed erythrocytes and numerous vacuoles are found in the cytoplasm of detached synovial cells and monocytes. The injected blood seems to be removed in 1 week. Regressive changes of the synovial membrane begin 2 weeks after the blood injection and they are conspicuous 4 weeks post injection. Medium size villi are flattened and microvilli are decreased in number and height at that time.

This study was planned to clarify the surface modifications of the synovial membrane after experimentally induced hemarthrosis. Observations of experimental hemarthrosis have been published by many authors (KeY, 1929; Soevr, 1949; Wolf, and Mankin, 1965; Roy and Ghadially, 1966; Guicciardi and Little, 1967; Guicciardi and Manenti, 1967; Ghadially and Roy, 1967; Hoaglund, 1967; Roy et al., 1967; Roy, 1968; CABANEL et al., 1971) using repeated injections of blood. In order to better understand the pathogenesis of the hemophilic arthropathy, we attempted to determine whether a single episode of hemarthrosis induces any changes on the synovial surface, and whether a good functional recovery occurs as is usually experienced after surgical operations of joints with perfect anatomical repair and as suggested by some authors (SoEUR, 1949; GoldIE, 1971). We used the scanning electron microscope for this purpose because the surface modifications are recognizable early well and this microscope permits examination of extensive areas. So far as the authors know, the scanning electron microscope has not yet been used to observe modifications of the synovial membrane induced by hemarthrosis. Our experimental design is believed to be very similar to the natural condition because no anticoagulative substances were added to the blood before injection into the the joint, and autologous blood was used.

\footnotetext{
* On leave from the Department of Orthopedics and Traumatological Surgery, Pavia University, Pavia, Italy as a Research Fellow from October 1, 1972 to March 31, 1973.
} 


\section{Materials and Methods}

Young adult rabbits were used for this experiment. Under sodium pentobarbital anesthesia, $1.5 \mathrm{cc}$ of blood was aspirated into a sterile syringe from an ear vein. After depilation and wetting the skin over the knee joint with $70 \%$ alcohol, the blood from the same animal was injected into the joint space of the right knee joint; the left one was used as control. No anticoagulant was used. After 2, 3, 7, 10 days and 2, 3, 4 weeks the knee joint was opened under general anesthesia with sodium pentobarbital, and synovial membrane was removed from the subpatellar pouch and the parameniscal zones. The specimens were cut in pieces about $0.5 \times 0.5 \times 0.2 \mathrm{~cm}$. They were carefully washed with physiological saline and fixed with cold $2 \%$ glutaraldehyde buffered with phosphate $(\mathrm{pH} 7.4)$ and postfixed with $1 \% \mathrm{OsO}_{4}$.

After washing with distilled water, the specimens were dehydrated through a series of acetone from $50 \%$ to absolute, and dipped into amylacetate. They were dried by Anderson's critical point method (modification by TANAKA, 1972) and coated with carbon and gold in a vacuum evaporator. They were examined in a JMS-U3 scanning electron microscope (Japan Electron Optics Laboratories Co. Ltd) with 10 or $15 \mathrm{kV}$ accelerating voltage.

Synovial fluid was removed from the joint space, smeared on a glass slide, stained with Giemsa solution and examined with a light microscope. Control blood taken from an ear vein of normal rabbits was examined. Synovial membrane cells from the control knee joint were also examined by touch preparation on a glass slide, after complete washing out of the synovial fluid.

\section{Observations}

The specimens obtained from the normal synovial membrane by touch preparation show isolated or clustered mononucleated cells. Their oval nuclei contain a fine chromatin network and 1 to 3 nucleoli. The rich basophilic cytoplasm has a fine granular structure and sometimes a few vacuoles. The cells often have cytoplasmic processes, varying in shape and size. Normal synovial fluid contains the same kind of cells, mostly isolated but sometimes arranged in small clusters (Fig. 1a). They are believed to be detached synovial cells.

The specimens of blood shows normal features. The monocytes have more

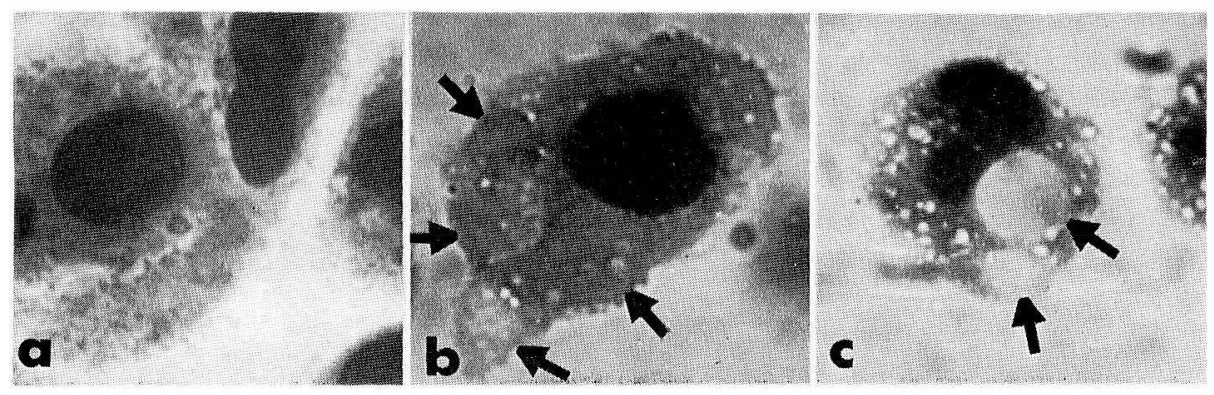

Fig. 1. Synovial fluid (light microscope). a. Normal detached synovial cells. b and c. Three days after the blood injection. Note erythrocytes (arrows) and numerous vacuoles in a synovial cell (b) and a monocyte $(\mathbf{c}) . \quad \times 1,500$ 
abundant cytoplasm than in lymphocytes, their nuclei are kidney-shaped or invaginated, the chromatin zone is lighter than that of lymphocytes and nucleoli are only rarely observable.

Two and three days after injection of the blood the synovial fluid is pink-brown, and increased in quantity but less than the normal amount of synovial fluid plus the blood injected. With light microscopy two types of mononuclear cells are predominant in addition to many erythrocytes. The first type corresponds to the cells visible in the normal synovial fluid and in specimens seen by touch preparation of the normal synovial membrane. However, they are more round than normal cells and contain phagocytozed erythrocytes and numerous cytoplasmic vacuoles (Fig. 1b). The cells of the second type are smaller, with scanty, more basophilic cytoplasm and concave or invaginated nuclei with occasional nucleoli, thus resembling the monocytes in the control blood. These cells also contain vacuoles and phagocytosed erythrocytes (Fig. 1c).

Specimens of synovial fluid removed 1 week after the blood injection no longer contain erythrocytes, and cells of the first type which resemble synovial cells, show no erythrophagocytosis, although many vacuoles occur in their cytoplasm. Cells of the second type are decreased in number.

Four weeks after the injection, most of the free synovial cells have normal features; the vacuoles are decreased in number and only a few cells have vacuolated cytoplasm. No evidence of infection was found in any of the specimens of synovial fluid.

The fresh specimens of synovial membrane in the control joint were normal in appearance both macroscopically and stereomicroscopically. Two or three days after the blood injection, the membrane is changed to a light pinkish brown due to hyperemia. The villi tend to be hypertrophic and to grow over other joint elements. Many enlarged blood vessels in the underlying tissue are visible. After 1 week the synovial membrane undergoes hypertrophy and hyperplasia; its color is more brownish in some areas and pinkish in others. The proliferation of the synovial membrane is especially recognizable over the cruciate and collateral ligaments and parameniscus. Numerous vessels are enlarged. Macroscopically the 10 day and 2 week specimens are little different from the 1 week specimens. Three and 4 weeks after the blood injection, the synovial membrane is yellowish brown without pink areas. At that time many adhesions are visible especially between the subpatellar pouch and the cruciate ligaments and in the paracondyle. Only a few blood vessels are recognizable, and hyperplasia of the synovia remains.

With the scanning electron microscope, the normal synovial membrane is seen to contain three recognizable orders of villi: macrovilli, medium size villi and microvilli. The first are formed by connective tissue covered by synovial cells. They can also be easily recognized under the low magnification stereomicroscope. The medium size villi corresponding to lining cells or to their large processes, are hardly recognized with the light microscope (Fig. 2a). The villi of the third order are represented by small cytoplasmic processes and cover the surface of the medium size villi. They are visible only with the electron microscope (Fig. 2b).

Two days after the injection, early modifications of the synovial membrane are recognizable especially at medium and high magnifications. It is easier to distinguish 




Fig. 2. Scanning electron micrographs of normal synovial membrane. a. Two types of medium size villi $(C$ and $P$ ). They correspond to protruding synovial cells $(C)$ and large cytoplasmic processes of synovial lining cells $(P)$ respectively. $\quad$ b. Numerous microvilli covering the medium size villi. a. $\times 500$, b. $\times 5,000$ 

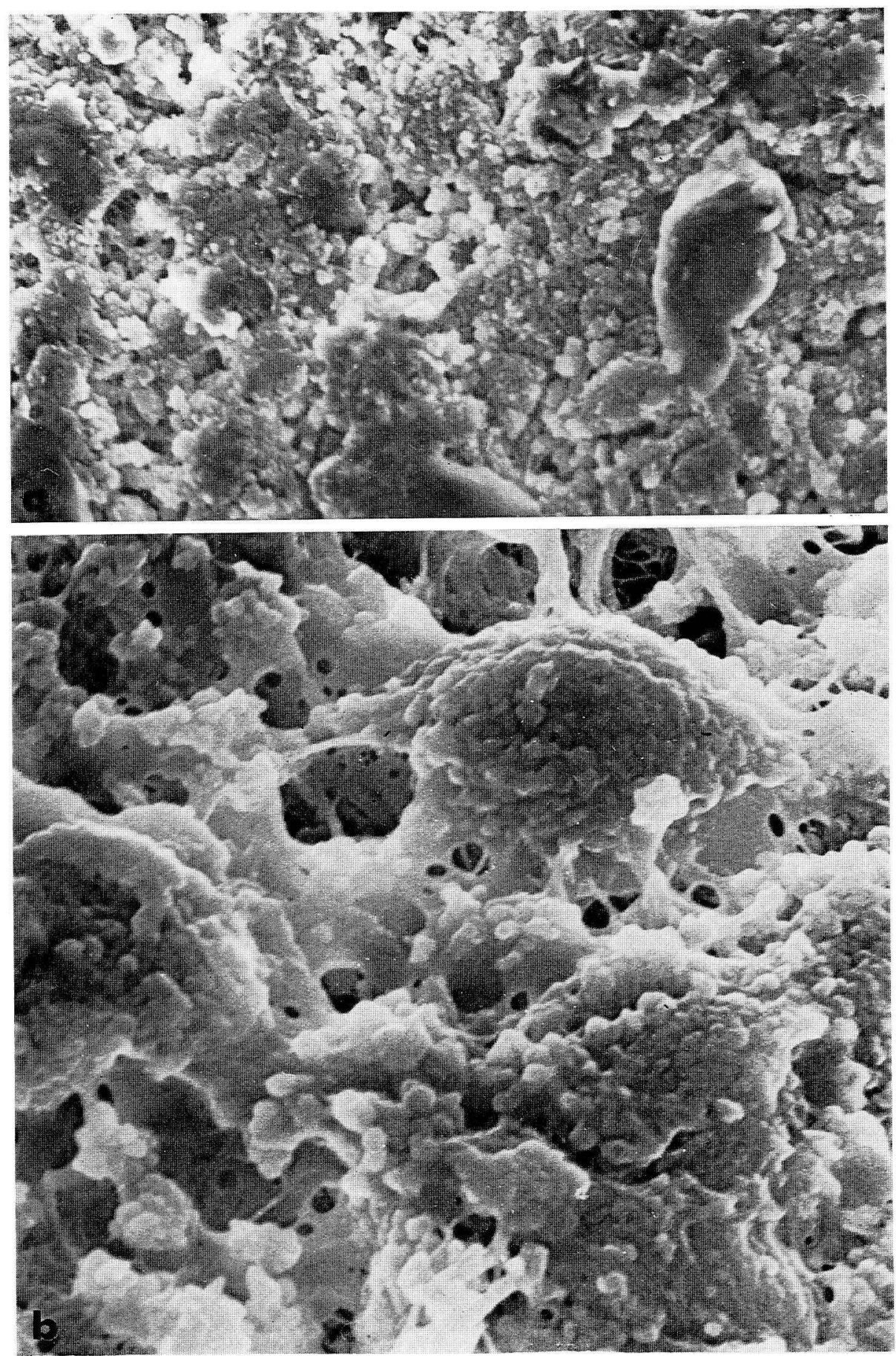

Fig. 3. Synovial surface $48 \mathrm{hrs}$ after blood injection. a. Protruding lining cells and their cytoplasmic processes at medium magnification. b. Enlarged intervillous spaces with holed membranes and filamentous processes. Numerous microvilli are projecting from medium size villi and large membrano-filamentous processes. a. $\times 1,500$, b. $\times 7,000$ 
the protruding lining cells and projecting cytoplasmic processes of the medium size villi. Both are more numerous than in the control specimens (Fig. 3a). The cells are more irregular in shape and their processes are longer. The intervillous spaces are enlarged and resemble a honey-comb divided into numerous concamerations by numerous holes and filamentous processes varying greatly in size and in shape. The processes cross over the honey-comb holes in many directions, and connect the medium size villi with each other (Fig. 3b). The microvilli are more irregular and larger than normal. They project from the larger filamentous and membranous processes.

Three days after injection of the blood, the synovial surface modifications are visible also at low magnification. There is hypertrophy of macrovilli and irregular aspect of medium size villi with many filamentous processes connecting one another like a spider web. Medium and high magnification observations show an increase of the microvilli, while the lining cells are easy to recognize due to the dilated intervillous space as compared with the 2 day specimens.

One week after the blood injection, the hypertrophy of macrovilli is still visible at low magnification. At medium and high magnification (Fig. 4) one finds numerous thick and thin filamentous processes, differing in shape from the 2 and 3 day specimens. They connect with one another and with the medium size villi. At high magnification, the surface pattern of the protruding lining cells often resembles the

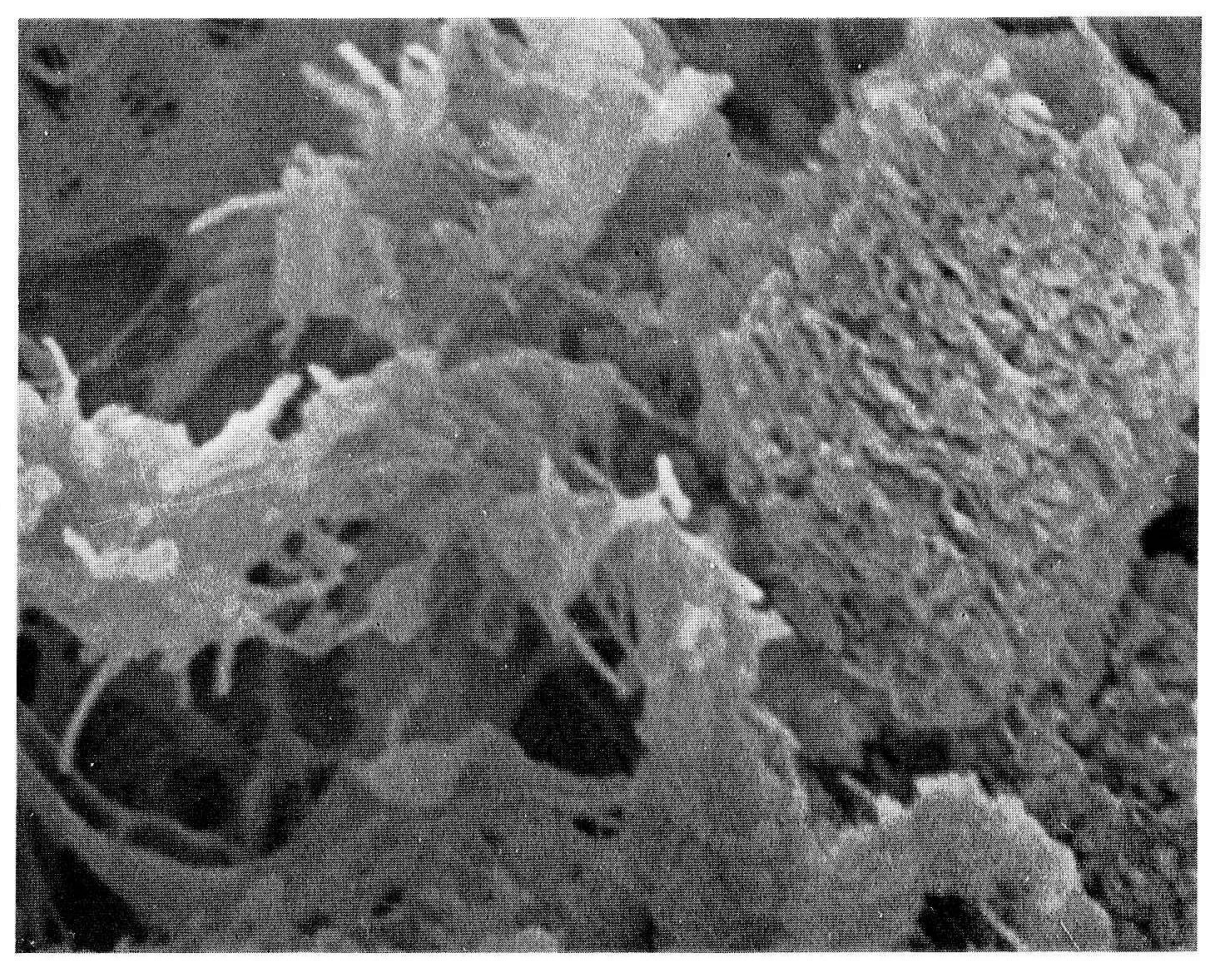

Fig. 4. Synovial surface 1 week after: blood injection. Fold-like microvilli on the protruding cells and spine-like microvilli on the large filamentous processes. $\quad \times 10,000$ 
macroscopic appearance of gastric mucosa. A conspicous change can be seen in the microvilli. They look like needles, spines or thin folds covering the medium size villi. Most of microvilli on the thick filamentous processes are thinner and taller than those of 2 and 3 day specimens.

Ten days after the blood injection, the synovial membrane seems little different from the 1 week specimen. At low magnification, hypertrophy of macrovilli is always present (Fig. 5), and the synovial membrane looks like grass, from which the medium size villi protrude as flowers. The medium size villi are more rounded and smaller than in the 1 week specimen. Microvilli are thinner and decreased in number.

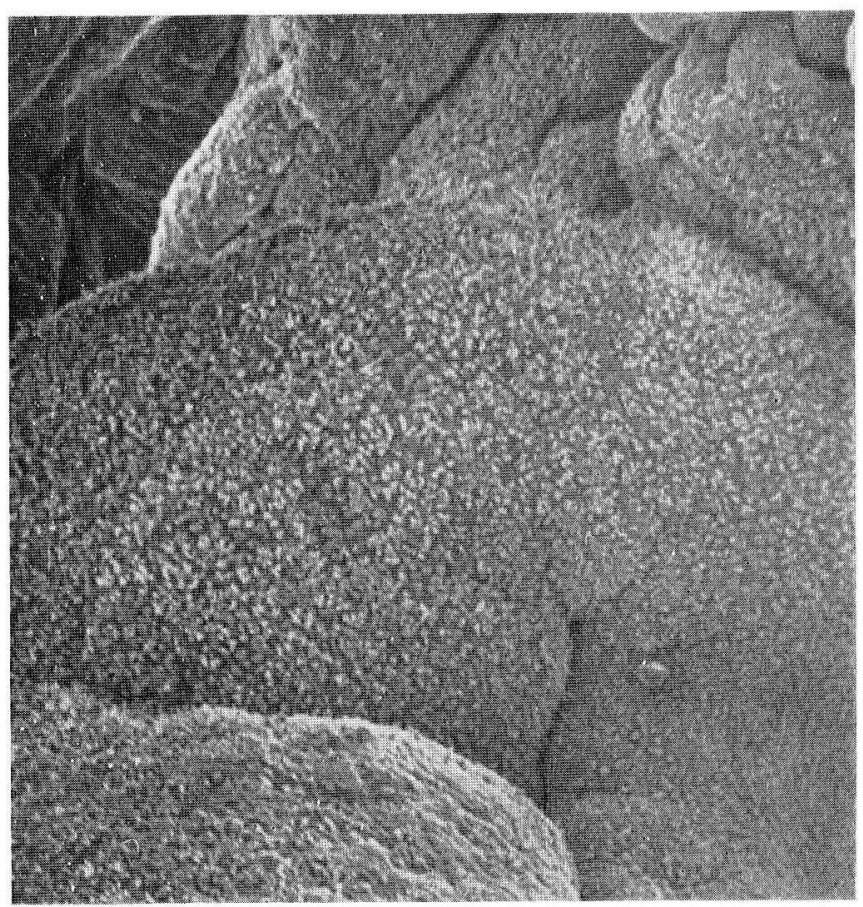

Fig. 5. Synovial surface 10 days after blood injection showing hypertrophy of macrovilli. $\times 130$

In the 2 week specimens, the synovial surface is not homogeneous. In some areas fiber-like material is visible. At medium and high magnifications these areas show only a few large filamentous cytoplasmic processes. Rounded cell protrusions are united by numerous fibers which are lower and larger in diameter and sometimes with smooth surfaces (Fig. 6b). In other areas, there are numerous large filamentous cytoplasmic processes, standing as trees, often with many ramifications, while the round cell protrusions are fewer in number and taller than those in the previously clescribed areas (Fig. 6a). On the rounded protrusions, the fold-like microvilli are decreased in height and in number, so that the surface is smoother, while on the large filamentous processes the spine-like microvilli are always present without any change from the 1 week specimens. 

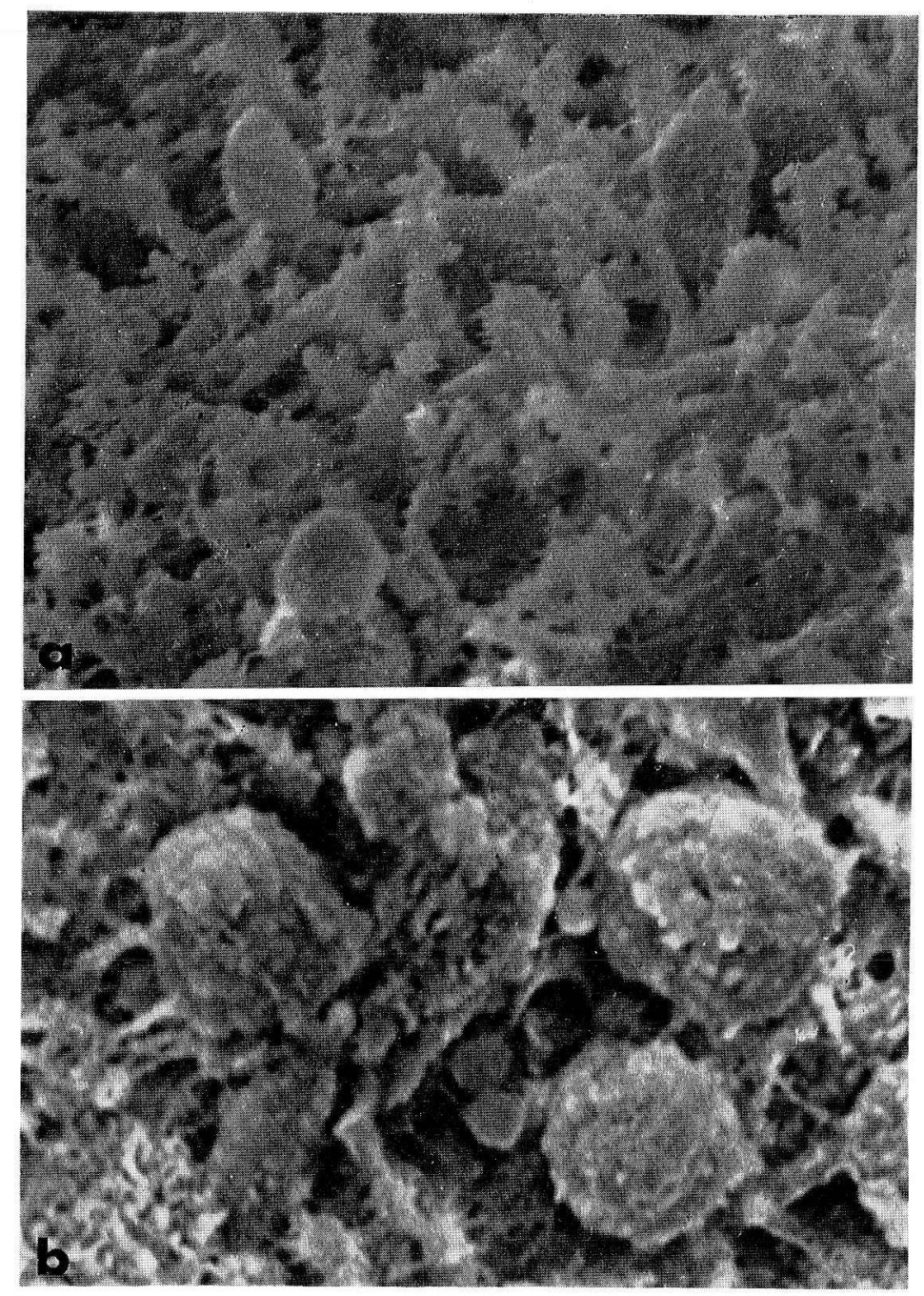

Fig. 6. Synovial surface 2 weeks after blood injection. a. Cellular protrusions and tree-like cytoplasmic processes. b. The tree-like processes are no longer present and the beginning of the collapse of medium size villi is indicated, a. $\times 1,200$, b. $\times 3,000$

Three weeks after the blood injection, the macrovilli are still hypertrophic, and their surface appears smooth because of the flattened medium sized villi. Compared with the 2 week specimens medium and high magnifications demonstrate the rounded cell protrusions to be lower, larger and to appear collapsed. These cell protrusions connect with one another to make a very close-meshed horizontal net (Fig. 8). Large filamentous processes are no longer found. A small number of flattened, granule-like microvilli replace the tall spine-like or fold-like microvilli. In very restricted areas, the incompletely collapsed cytoplasmic processes are still recognizable with an 
appearance of specimens between the 2 and 3 week stage. Some of the microvilli are thin and standing, but most of them are granule-like.

Four weeks after the blood injection, a completely smooth synovial surface is seen at low magnification, and the protruding medium size villi are not recognizable. At higher magnification, collapsed medium size villi protrude slightly from the flattened surface (Fig. 9a). They vary in shape and in size and are almost without any roughness. Only a few have granule-like microvilli on their surface (Fig. 9b).

\section{Discussion}

The appearance of normal synovial membrane, as obtained from the control knee joints, is similar to the description by Fujita et al., (1968). Three orders of villi are recognizable in the synovial surface (1) macrovilli, (2) medium size villi equivalent to either large filamentous cytoplasmic processes or protruding lining cells,

Fig. 7. Three weeks after blood injection showing sharp-edged macovilli with smooth surface because of the flattened medium size villi. $\times 120$
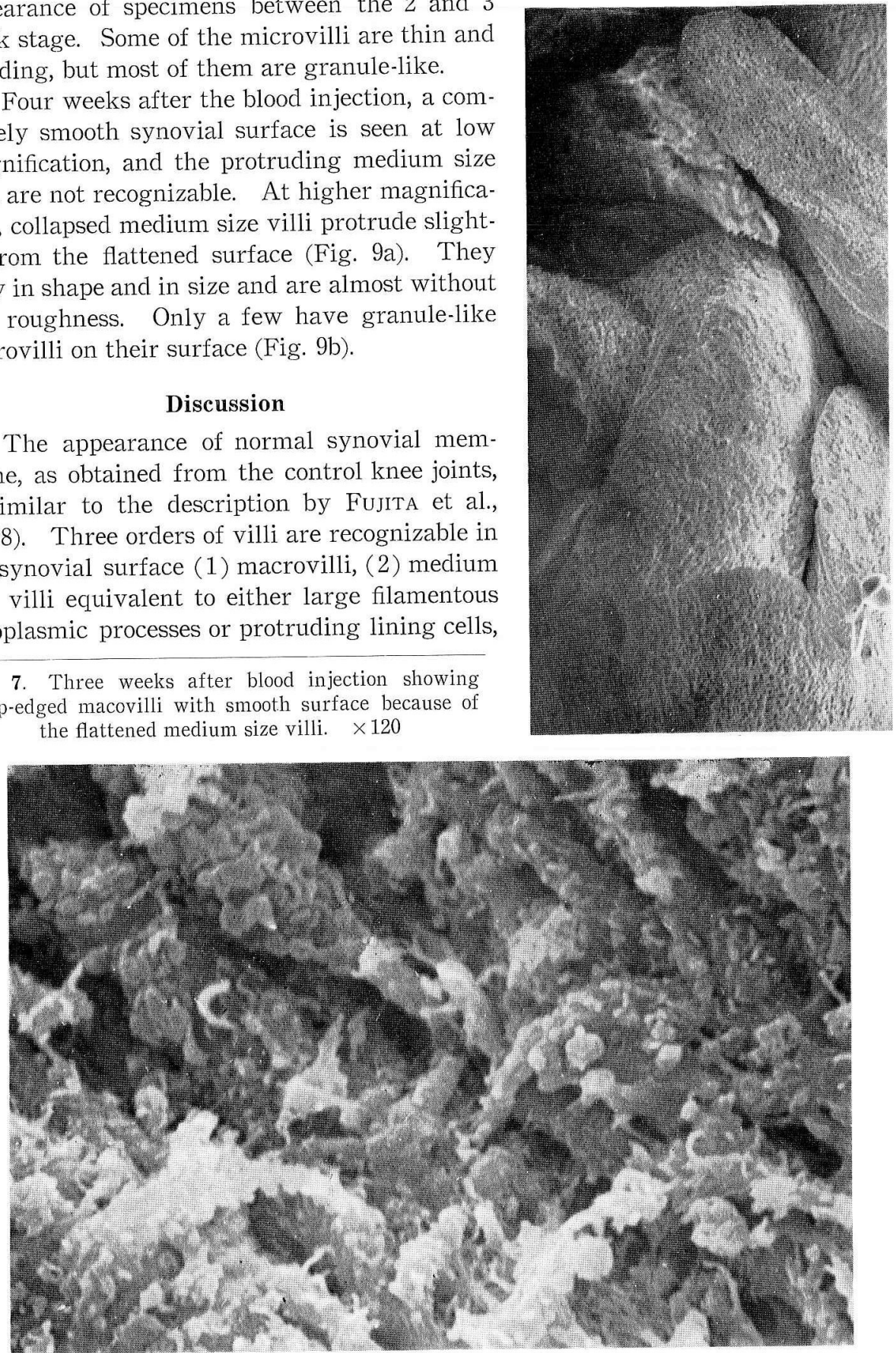

Fig. 8. Synovial membrane 3 weeks after blood injection. Large filamentous processes are no longer standing and they are covered by low granular microvilli. $\times 5,000$ 

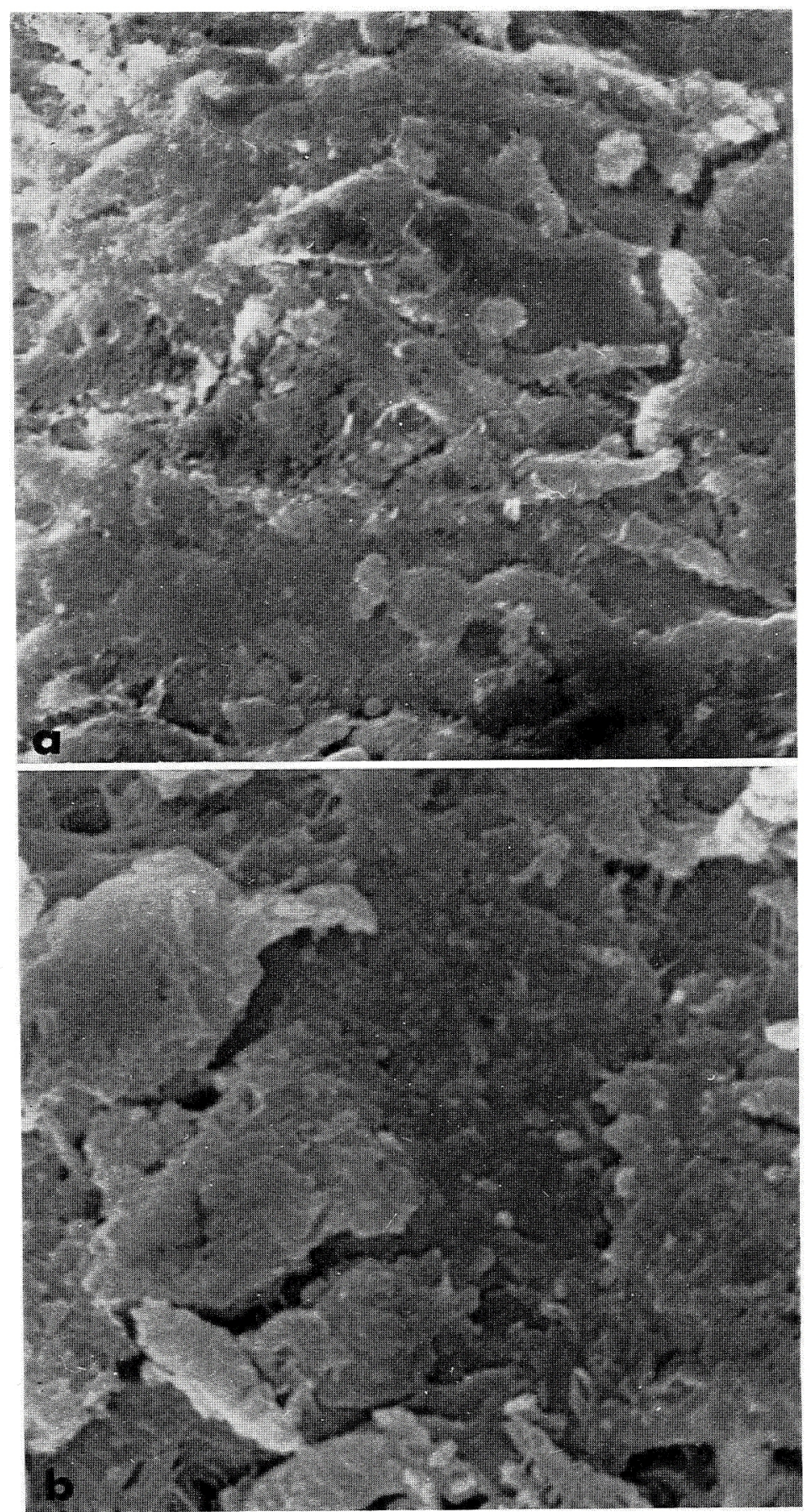

Fig. 9. Synovial surface 4 weeks after blood injection. Collapsed medium size villi adhere to the supporting tissue $(\mathbf{a}, \mathbf{b})$ covered by only a few flattened granular microvilli (b). a. $\times 2,000$, b. $\times 6,000$ 
and (3) microvilli. However, our scanning microscope investigation dose not permit differentiation of the two types of cells; type A cells with numerous vacuoles, lysosomal elements and prominent Golgi apparatus, and type B cells characterized by a large amount of ergastplasm, as described by BARLAND et al. (1962) in transmission electron microscope observations (LEver and Ford 1958; CASTER, 1960; GHAdIALly and Roy, 1966; LANGER and Huth, 1966; Woodward et al., 1969; RedLer and Zimmy, 1970).

After hemarthrosis induced by a single injection of blood, the first reaction of the synovial membrane is the increase in number and size of medium size villi and microvilli. The medium size villi corresponding to protruding lining cells become larger and more prominent. Numerous phagocytosed erythrocytes appear on the 2nd and 3rd days after the blood injection. The phagocytic cells might be derived from the protruding lining cells. Roy et al. $(1966,1967)$ found many phagocytosed erythrocytes in type A cells of the synovial membrane after the blood injection. We believe that most of protruding and detached lining cells are type A cells playing an important role in removing red cells from the joint space. It is probable that many type A lining cells loose their connections with the synovial membrane and contribute to the restoration of the synovial fluid by phagocytosis of erythrocytes and blood plasma in co-operation with monocytes. In our scanning electron microscope observations, we could not find direct evidence of erythrophagocytosis by synovial cells, though light microscope observations of the synovial fluid demonstrated this phenomenon.

The large cytoplasmic processes and the filament-membranous processes seem to contribute to the enlargement of the synovial surface. The increase in number of small cytoplasmic processes agrees with the description of the increase of philopodia in the transmission electron microscopy observations of Roy et al. $(1966,1967)$. We believe that these changes in the synovial surface are a reaction to the blood acting as a foreign material in joint space, and that they serve to accelerate the turnover of the components of the synovial fluid, so as to restore it to normal.

The macrovilli undergo hypertrophy 3 days after the blood injection, and this increases for 7-10 days. After the second week, the medium size villi and microvilli show regressive changes. The changes in size, shape and thickness seem to represent gradual degeneration, which is easily recognizable in the 4 week specimens. The authors think that the degenerative changes of the synovial surface begin just when normal synovial fluid has been restored, i.e., 10 days after the blood injection. Fibrosis of synovial supporting tissuse after the hemarthrosis was described by KEY (1929), Wolf and Mankin (1965), Guicciardi and Manenti (1967) and Roy (1968). The degenerative change are considered to be caused by 2 main factors; a) a direct irritative and degenerative effect of the injected blood on the synovial cells and $b$ ) altered nutrition resulting from decreased blood supply to the hypertrophic synovial membrane from the supporting tissue which is undergoing fibrosis.

The early changes are presumably due to the direct action of the injected blood and to the increased volume and pressure in the joint space, to both of which, the synovial membrane reacts with hypertrophy and hyperplasia of all its components. The subsequent synovial surface degeneration is probably due to the decrease of the blood supply and to the harmful effect on the cell of the blood degradation products.

Is the change observed in the synovial membrane reversible? KEY (1929), Soeur 
(1948), and Wolf and MANKIN (1965) described complete regression of the fibrosis in the synovial membrane within 6 months after repeated hemarthrosis. Also the possibility of the regeneration of the synovial membrane after synovectomy has been supported by many authors. Though our experiment was continued for too short a period to premit a decisive comment on this matter, we believe that, with the regression of the fibrosis of the supporting synovial tissue and the restoration of the normal blood supply, the structure of the synovial surface can be restored to normal.

\title{
実験的血関節症におけるカイウサギ膝関節滑膜の走査電子顕微鏡による観察
}

\author{
Paolo Cherubino と片岡勝子
}

\section{正常および自己血液注射後のカイウサギ膝関節の滑膜を走査電子顕微鏡により観察し た.}

1. 正常滑膜の表面は 3 段階の起伏を示す.すなわち a) 低倍の実体鏡で観察可能な 絨毛 (macovilli), b) 関節腔内に突出した表層細胞 (lining cells) およびその大きい突起 (medium size villi), c) 細胞の微細な突起 つまり 微絨毛 (microvili) が観察された.

2. 自己血液を関節腔内に注射すると，まず関節腔内に突出した表層細胞とその大き い突起の増加，ならびに不規則な microvilli の成長がみとめられた. この時期には滑 液中には 䕘食した赤血球と多くの空胞を含む細胞（剝脱した表層細胞と単球）が多数み とめられた。ついで macrovilli が肥大増殖して 他の関節要素の上におおいかぶさる像 が観察された。注射した血液は遅くとも 1 週間以内には 関節腔より排除されていた。

3. 絨毛の退行と萎縮は血液注射後 2 週間頃より始まり，4 週目には medium size villi や microvilli の平坦化が顕著であった.

\section{References}

Barland, P., A. B. Novikoff and D. Hamermann: Electron microscopy of the human synovial membrane. J. Cell Biol. 14: 207-220 (1962).

Cabanel, G., X. Phelip and J. P. Gras: Value of the study of the synovial fluid in hemarthrosis. Presse méd. 79: 1567, (1971).

Caster, C. M.: The microscopic structure of normal synovial tissue. Arthr. Rheum. 3: 140-151 (1960).

Fujita, T., H. Inoue and T. Kodama: Scanning electron microscopy of the normal and rheumatoid synovial membranes. Arch. histol. jap. 29: 511-522 (1968).

Ghadially, F. N. and S. Roy: Ultrastructure of rabbit synovial membrane. Ann. rheum. Dis. 25: 318-326 (1966).

Ann. rheum. Dis. 26: 117-122 (1967).

Goldie, I.: Pathomorphologic features in original and regenerated synovial tissues after synovectomy in rheumatoid arthritis. Clin. Orth. relat. Res. 77: 295-304 (1971).

Guicciardi, E. and K. Little: Some observations on the effects of blood and a fibrinolytic enzyme on articular cartilage in the rabbit. J. Bone Joint Surg. 49B: 342-350 (1967). 
Guicciardi, E. and W. Manenti: Osservazioni sugli effetti del sangue e di un enzima fibrinolitico sulla cartilagine articolare del ginocchio di coniglio. Atti Acc. Med. Lombarda, 22: 111-117 (1967).

Hoaglund, F. T.: Experimental hemarthrosis. The response of canine knees to injections of autologous blood. J. Bone Joint Surg. 49A: 285-298 (1967).

Key, J. A.: Experimental arthritis. J. Bone Joint Surg. 11: 705-712 (1929).

Langer, E. and F. Huth: Untersuchungen über den submikroskopischen Bau der Synovialmembran. Z. Zellforsch. 51: 545-559 (1966).

Lever, J. D. and E. H. R. Ford: Histological, histochemical and electron microscopic observations on synovial membrane. Anat. Rec. 132: 525-539 (1958).

Redler, I. and M. I. Zimmy: Scanning electron microscopy of normal and abnormal articular cartilage and synovium. J. Bone Joint Surg. 52A: 1395-1404 (1970).

Roy, S.: Ultrastructure of articular cartilage in experimental hemarthrosis. Arch. Pathol. (Chicago) 86: 69-76 (1968).

Roy, S. and F. N. Ghadially: Pathology of exeprimental hemarthrosis. Ann. rheum. Dis. 25: 402-415 (1966).

Roy, S., F. N. Ghadially and M. C. Path: Ultrastructure of synovial membrane in human hemarthrosis. J. Bone Joint Surg. 49A: 1636-1646 (1967).

Soeur, R.: The synovial membrane of the knee in pathological conditions. J. Bone Joint Surg. 31A: 317-340 (1949).

Tanaka, K.: Freezed resin cracking method for scanning electron microscopy of biological materials. Naturwiss. 2: 1-2 (1972).

Wolf, C. R. and H. J. Mankin: The effect of experimental hemarthrosis on articular cartilage of rabbit knee joint. J. Bone Joint Surg. 47A: 1203-1210 (1965).

Woodward, D. H., A. Gryfe and D. L. Gardner: Comparative study by scanning electron microscopy of synovial surfaces of four mammalian species. Experientia 25: 1301-1303 (1969).

片岡勝子

于734 広島市霞 $1 丁$ 目 $2-3$

広島大学医学部

第二解剖学教室
Dr. Paolo Cherubino

Assistente Universitario di Ruolo

Clinica Ortopedica e Traumatologica

Università di Pavia

Pavia, Italy

Dr. Katsuko KatAoKA

Department of. Anatomy

Hiroshima University School of Medicine

Hiroshima, 734 Japan 